Рекомендована д. біол. наук, проф. І. М. Кліщем

УДК 615.035.31:[616-052:378.046.4]:303.62

DOI 10.11603/2312-0967.2018.3.9323

\title{
СТАВЛЕННЯ ДО ПРОЦЕСУ САМОЛІКУВАННЯ ЗДОБУВАЧІВ ВИЩОЇ МЕДИЧНОЇ ОСВІТИ НА ДО- ТА ПІСЛЯДИПЛОМНОМУ ЕТАПІ (ЗГІДНО З РЕЗУЛЬТАТАМИ СОЦІОЛОГІЧНОГО ДОСЛІДЖЕННЯ)
}

\author{
(сН. І. Заремба, А. Б. Зіменковський \\ Львівський національний медичний університет імені Данила Галицького
natalyazaremba@gmail.com
}

Мета роботи. Попередження негативних наслідків самолікування на основі його вивчення та аналізу поведінки щодо даного питання здобувачів вищої медичної освіти та курсантів-медиків.

Матеріали і методи. Дослідження проводили за результатами соціологічного опитування $400(p<0,05)$ здобувачів освіти на до- та післядипломному етапі у Львівському національному медичному університеті імені Данила Галицького. Отриманий шляхом анкетування первинний науковий матеріал був проаналізований з використанням статистичного та структурно-логічного методів із врахуванням принципів системності. При статистичному аналізі отриманих даних було проведено розрахунок відносних величин та їх похибок. Використано методи системного аналізу, статистичний, соціологічний, порівняння.

Результати й обговорення. За результатами соціологічного дослідження встановлено, що більшість здобувачів вищої медичної освіти на до- та післядипломному етапі самостійно призначала лікування. Підставами для придбання ліків при гострих та хронічних захворюваннях найчастіше є призначення лікаря та особистий досвід опитаних. Третина анкетованих самостійно збільшували дозу ліків. Кожен 2-й респондент визнав, що змінював призначені лікарем лікарські засоби на більш дешеві аналоги. Кожен 2-й опитаний вважає, що за рецептом мають відпускатися зокрема оральні гормональні контрацептиви та антибіотики.

Висновки. Отримані та проаналізовані результати виконаного соціологічного дослідження засвідчують, що більшість анкетованих $(91,50 \pm 1,39)$ \% ствердили, що займались самолікуванням. За даними їх самооцінки, 3-поміж них у 64,5 \% не відбулося досягнення терапевтичного ефекту ліків. Більшість респондентів $(64,00 \pm 2,40) \%$ визнали, що зазвичай приймають більше одного лікарського засобу одночасно. Перед прийманням ліків інструкцію до медичного застосування лікарського засобу вивчає більшість респондентів. Отримані результати, на нашу думку, повинні стати основою у комплексній моделі програми попередження негативних наслідків самолікування, особливо серед молоді.

Ключові слова: соціологічне дослідження; самолікування; здобувачі вищої медичної освіти на до- та післядипломному етапі; лікарські засоби; поліпрагмазія.

Вступ. На даний час самолікування все частіше трапляється в повсякденному житті. Люди відмовляються від допомоги лікарів і самостійно обирають собі лікування, на задумуючись про можливу шкоду для власного здоров'я. Таким чином, значна частка населення вважає, що самолікування дозволяє економити час і гроші й суттєво не відрізняється від лікування, призначеного лікарем [1, 2].

Закономірно, що виникає багато ризиків, пов'язаних із самодіагностикою, відсутністю усвідомлення споживачами можливих негативних наслідків самостійного приймання ліків, резистентності мікрофрлори, переходом хвороби у хронічну фрорму. Самолікування нерідко завдає шкоду, яка виникає через неправильні приймання власне безрецептурних лікарських засобів (Л3), так і ліків для самолікування абсолютно не призначених або протипоказаних $[3,4]$.
Зокрема, за даними ретроспективного аналізу медичних карт пацієнтів із гострими отруєннями Л3, у $10 \%$ випадків причиною отруєнь були саме безрецептурні ЛЗ [5]. За даними ДЕЦ МОЗ України, найбільш поширеними негативними наслідками самолікування є алергічні реакції (84,3 \%), серед них реакції з боку шкіри - 44,3 \%, набряк Квінке - 21,5 \%, інше - 34,2 \%; анасрілактична реакція (5,2 \%), ураження травного тракту (3,1\%), локальна реакція в місці введення Л3 (1,1\%), ураження центральної нервової системи (4,2 \%), ураження дихальних шляхів $(2,1 \%)$ [6].

Із вищевказаних причин актуальним, на нашу думку, є вивчення організації відпуску лз без рецепту та розробка концепції відповідального самолікування і безрецептурного відпуску ліків населенню в Україні. Водночас вважаємо, що правильно організована санітарно-просвітницька робота серед населення, осо-

ISSN 2312-0967. Фармацевтичний часопис. 2018. № 3 
бливо молоді, дозволить зробити процес самолікування контрольованим та відповідальним $[7,8]$.

Мета роботи - попередження негативних наслідків C на основі його вивчення та аналізу поведінки щодо цього питання здобувачів вищої медичної освіти та курсантів-медиків.

Завдання дослідження. 1. Дослідити, вплив самолікування у процесі фрармакотерапії (ФТ) і терапевтичний ефект. 2. Визначити мотивацію населення щодо придбання ліків при гострих та хронічних захворюваннях. 3. Проаналізувати думку респондентів щодо адекватної кількості ліків для ФТ та поліпрагмазії. 4. 3'ясувати чи дотримуються респонденти інструкції до медичного застосування ЛЗ чи вказівок рецептів та які ліки мають відпускатися за рецептом. 5. Визначити, яку суму в середньому витрачають респонденти при одному зверненні в аптеку.

Матеріали і методи. Дослідження проводили за результатами соціологічного опитування $400(p<0,05)$ здобувачів освіти на до- та післядипломному етапі у Львівському національному медичному університеті імені Данила Галицького (ЛНМУ) (табл. 1).

Отриманий шляхом анкетування первинний науковий матеріал проаналізовано з використанням статистичного та структурно-логічного методів із врахуванням принципів системності. При статистичному аналізі отриманих даних проведено розрахунок відносних величин та їх похибок. Використано методи системного аналізу, статистичний, соціологічний, порівняння.

Результати й обговорення. За результатами проведеного соціологічного дослідження встановлено, що в $(91,50 \pm 1,39) \%$ анкетованих здобувачів освіти на до- та післядипломному етапі підготовки трапляються випадки, коли респонденти самостійно призначають медикаментозне лікування, тобто займаються самолікуванням. При цьому встановлено, що 3-поміж них $(68,50 \pm 2,32) \%$ застосовують його рідко, а $(23,00 \pm 2,10) \%$ анкетованих займаються самолікуванням завжди. Водночас лише $(8,50 \pm 1,39)$ \% опитаних майбутніх лікарів та провізорів стверджують, що ніколи самі собі не призначають ФТ.

Важливим було визначити думку анкетованих, чи завжди вони досягали терапевтичного ефекту при самолікуванні. Методом самооцінки анкетованих було отримано такі результати: 1) $(45,50 \pm 2,49) \%$ рес- пондентів вважають, що самолікування завжди було еорективним; 2) практично стільки ж респондентів $(47,75 \pm 2,50)$ \% не завжди досягали терапевтичного есректу у випадках, коли самі собі призначали ФТ; 3)

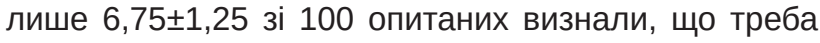
було все ж звертатися до лікаря. Варто зазначити, що отримані результати ФТ базувалися на суб'єктивних відчуттях пацієнтів (тобто методі самооцінки), а не згідно з даними достовірних медичних обстежень. Таким чином, вважаємо, що у 64,5 \% пролікованих самостійно пацієнтів однозначно не відбулося покращення їх стану здоров'я, і ця частка може бути об'єктивно більшою у випадку залучення кваліфрікованих медичних фрахівців до процесу оцінки результатів ФТ.

У ході подальшого дослідження ми попросили респондентів відповісти на запитання, що є підставою для того, щоб вони придбали ліки при гострих захворюваннях (рис. 1). Аналіз отриманих даних засвід-

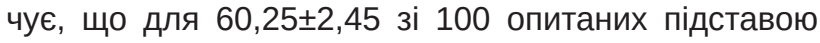
для придбання ліків все ж $є$ призначення лікаря. Кожен 2-й $(53,25 \pm 2,49)$ \% заявив, що купує ліки, керуючись особистим досвідом, а кожен 5-й респондент $(21,25 \pm 2,05) \%$ - порадою родичів чи друзів. Інформації 3 інтернет-сайтів та з реклами по мас-медіа довіряють $(9,25 \pm 1,45) \%$ та $(2,75 \pm 0,82) \%$ анкетованих відповідно.

Окрім наведеного, під час виконання соціологічного дослідження вивчали підстави (мотивація) для придбання ліків при хронічних захворюваннях (рис. 2). Виходячи з гіпотези, що не у всіх анкетованих можуть мати місце хронічні захворювання, ми встановили наступне. Тож, $(47,50 \pm 2,50) \%$ респондентів ствердили, що хронічні захворювання в них відсутні, а решта $(52,50 \pm 2,50) \%$ - склали аналізовану підгрупу. Відтак 3-поміж тих анкетованих, хто вказали на наявність хронічних захворювань, підставою для придбання ліків найчастіше було призначення лікаря $(63,49 \pm 3,03)$ \%. Кожен 4-й 3 анкетованих $(25,79 \pm 2,76) \%$ стверджував, що враховує особистий досвід при купівлі ліків. Водночас рекомендації провізора аптеки та поради родичів чи друзів $є$ визначальними у прийнятті рішення для незначної частки досліджуваних $((4,76 \pm 1,37)$ \% та $(3,57 \pm 1,17)$ \% відповід-

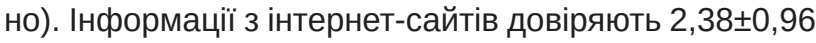
зі 100 анкетованих. Цікавим, на нашу думку, є той фракт, що рекламі по радіо та телебаченню щодо ФТ

Таблиця 1. Основні характеристики описової статистики респондентів (n=400)

\begin{tabular}{|l|c|}
\hline Загальна кількість опитаних, N & 400 \\
\hline Стать & $120(30 \%)$ \\
Чол., абс (\%) & $280(70 \%)$ \\
Жін., абс (\%) & $21,15 \pm 3,43$ \\
\hline Середнє значення віку респондентів, роки \pm SD & $17-50$ \\
\hline Вік опитаних, роки min - max & \\
\hline
\end{tabular}

Примітка. * SD - standard deviation.

ISSN 2312-0967. Pharmaceutical review. 2018. № 3 
Фармацевтична освіта

Pharmaceutical education

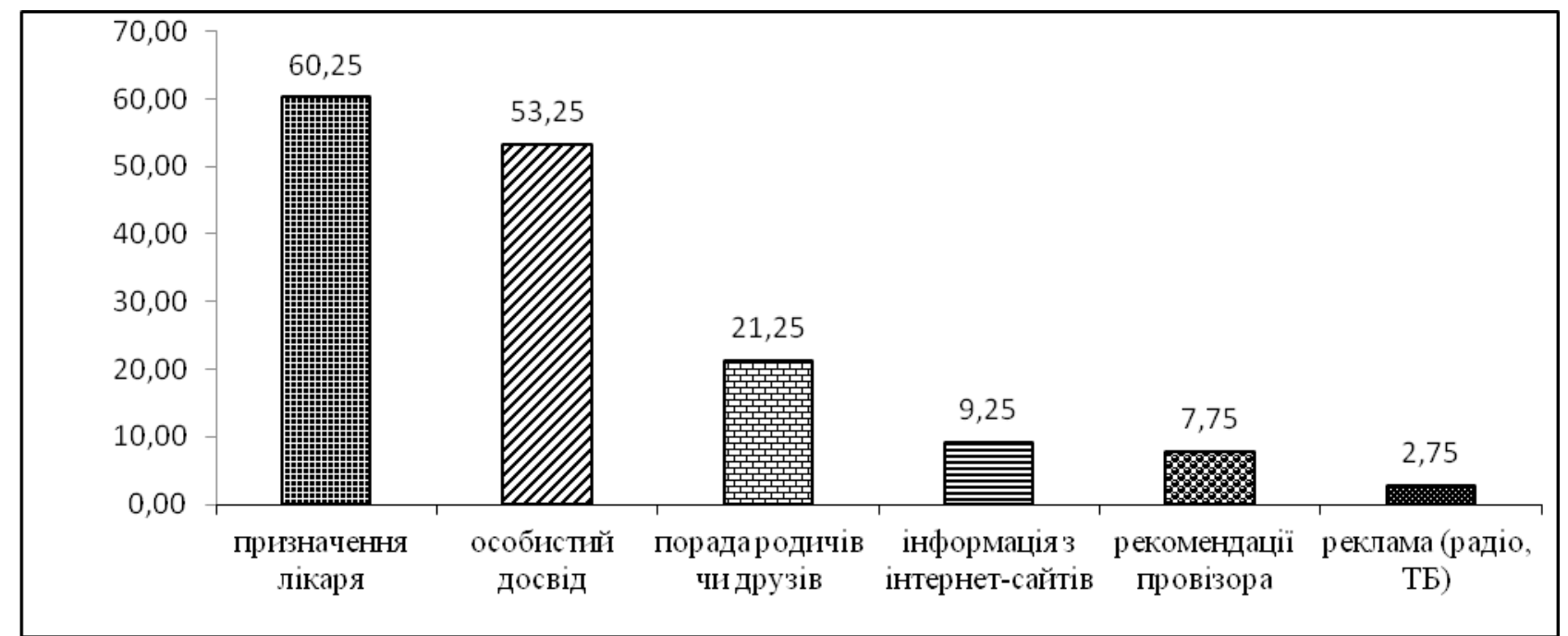

Рис. 1. Розподіл відповідей здобувачів вищої медичної та фрармацевтичної освіти на до- та післядипломному етапі (випадки на 100 анкетованих) щодо підстав для придбання ліків при поширених гострих захворюваннях.

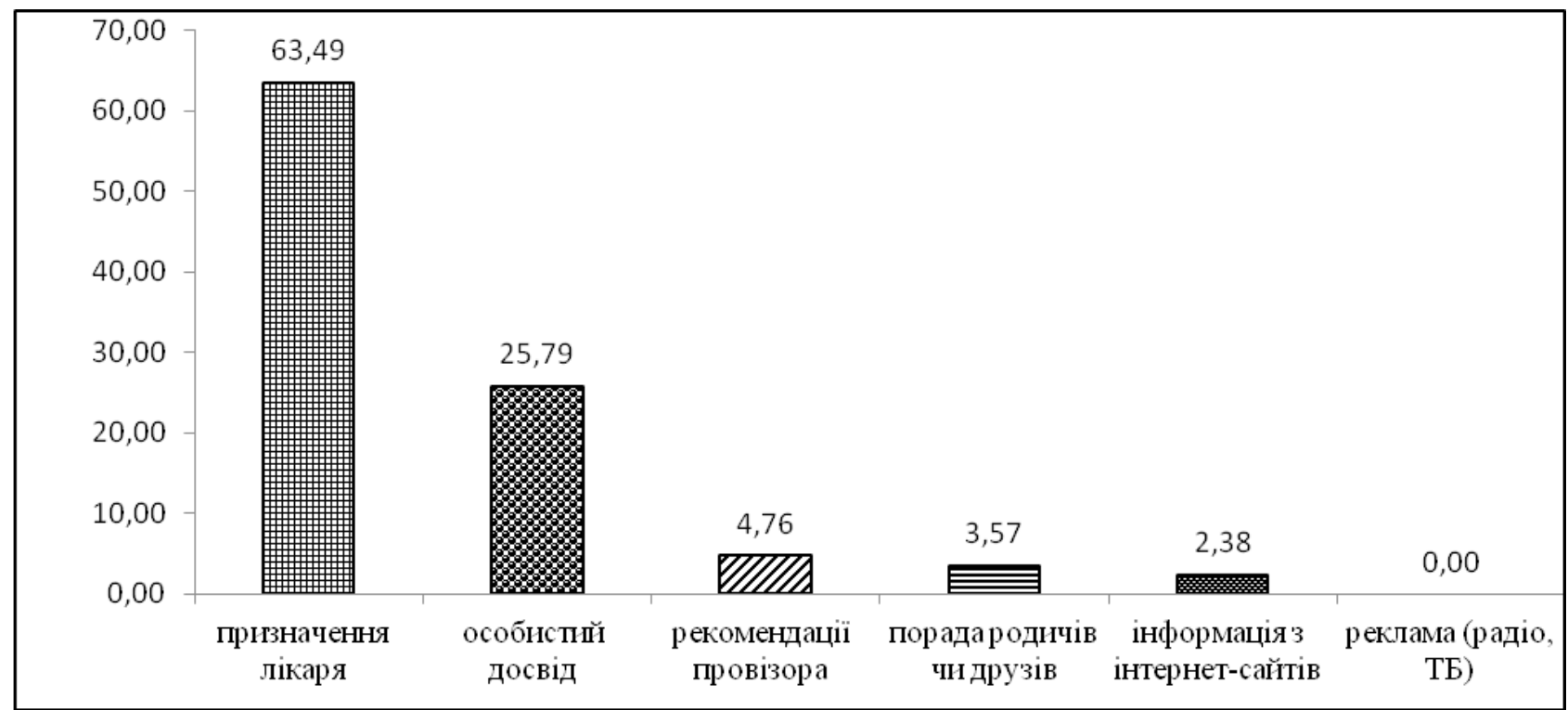

Рис. 2. Розподіл відповідей здобувачів вищої медичної та фрармацевтичної освіти на до- та післядипломному етапах (випадки на 100 анкетованих) щодо підстав для придбання ліків при хронічних захворюваннях.

хронічних захворювань не довіряє жоден із респондентів.

Шляхом рандомізованого анкетування ми вивчали думку студентської молоді про те, яку кількість призначених ліків одночасно можна вважати адекватною. Отримані відповіді засвідчують, що більшість 76,75 2,11 зі 100 опитаних, трактують як прийнятну кількість до 5-ти ліків. Тоді як $(4,00 \pm 0,98) \%$ респондентів вважають адекватним призначення водночас не більше 10-ти ліків. Проте варто зазначити, що кожен 5-й респондент $(19,25 \pm 1,97) \%$ вагався щодо однозначної відповіді на це запитання. Це свідчить, на нашу думку, про те, що питання визначення поліпрагмазії й далі залишається недиференційованим, навіть серед медичної спільноти.
Водночас анкетованим було запропоновано висловити власну думку на запитання: «Що Ви вважаєте поліпрагмазією (полісрармацією)?». Аналіз отриманих результатів показує, що опитані в $(43,00 \pm 2,48) \%$ випадках вважають поліпрагмазією одночасне приймання 6-ти і більше ліків. Тоді як

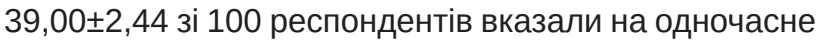
приймання від 3-х до 5-ти ліків. Кожен п'ятий $(18,00 \pm 1,92) \%$ анкетований схильний називати поліпрагмазією одночасне приймання 2-х ліків.

Вивчено відповіді на запитання, чи часто трапляється так, що респонденти водночас приймають більше одного Л3. Більшість опитаних $(64,00 \pm 2,40) \%$ визнали, що часто приймають більше одного ЛЗ одночасно, тоді як $36,00 \pm 2,40$ із 100 опитаних цей фракт заперечили.

ISSN 2312-0967. Фармацевтичний часопис. 2018. № 3 
Окрім наведеного, визначено при якому ступені погіршення самопочуття респонденти самовільно вирішують прийняти ліки. Аналіз отриманих резуль-

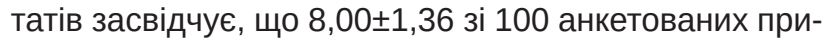
ймають ліки при відчутті найменшого дискомфорту. Однак більшість опитаних $(78,00 \pm 2,07)$ \% стверджує, що приймають ЛЗ тільки при значному погіршенні са-

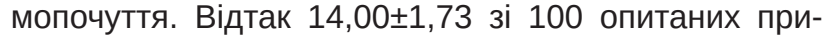
ймають ліки лише тоді, коли дискомфорт стає нестерпним.

Цікаво, на нашу думку, що перед прийманням ліків інструкцію до медичного застосування ЛЗ вивчають завжди 60,50 22,44 зі 100 респондентів; інколи чита-

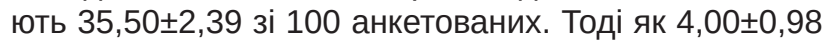
зі 100 респондентів неознайомлюють 3 інструкцією взагалі.

У процесі виконання соціологічного дослідження з'ясовано, чи бувають випадки, коли респонденти збільшували дозу ЛЗ з метою пришвидшення одужання. При цьому встановлено, що $(34,75 \pm 2,38) \%$ анкетованих самовільно збільшували дозу ЛЗ, тоді як $65,25 \pm 2,38$ зі 100 опитаних засвідчили, що таких випадків у них не було.
Визначено, наскільки часто респонденти змінювали призначені лікарем ліки на більш дешеві аналоги. Стосовно цього питання, 45,25 22,49 зі 100 респондентів визнали, що дійсно змінювали призначені лікарем ліки на більш дешеві аналоги. Хоча більшість анкетованих $(54,75 \pm 2,49)$ \% все ж відповіли негативно.

Вивчали думку анкетованих, які ліки мають відпускатися за рецептом (рис. 3). Аналіз отриманих даних засвідчує, що кожен 2-й респондент вважає, що за рецептом мають відпускатися оральні гормональні контрацептиви та антибіотики $((52,50 \pm 2,50) \%$ та $(51,00 \pm 2,50)$ \% відповідно). Окрім цього, респонденти у відповідях зазначили ненаркотичні анальгетики $(12,00 \pm 1,62) \%$; нестероїдні протизапальні засоби $(11,00 \pm 1,56) \%$; та навіть вітаміни $(3,75 \pm 0,95) \%$.

3'ясовано, що при одному зверненні в аптеку

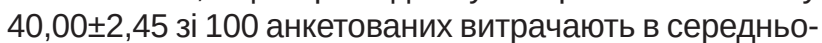
му до 100 грн. Кожен 2-й респондент $(49,00 \pm 2,50) \%$ зазначив суму від 100 до 300 грн, тоді як в середньому 300-500 грн витрачають при кожному зверненні

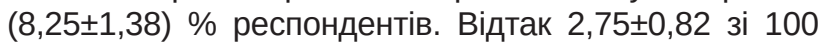
опитаних при одноразовому зверненні в аптеку оплачують ліки на суму більше 500 грн.

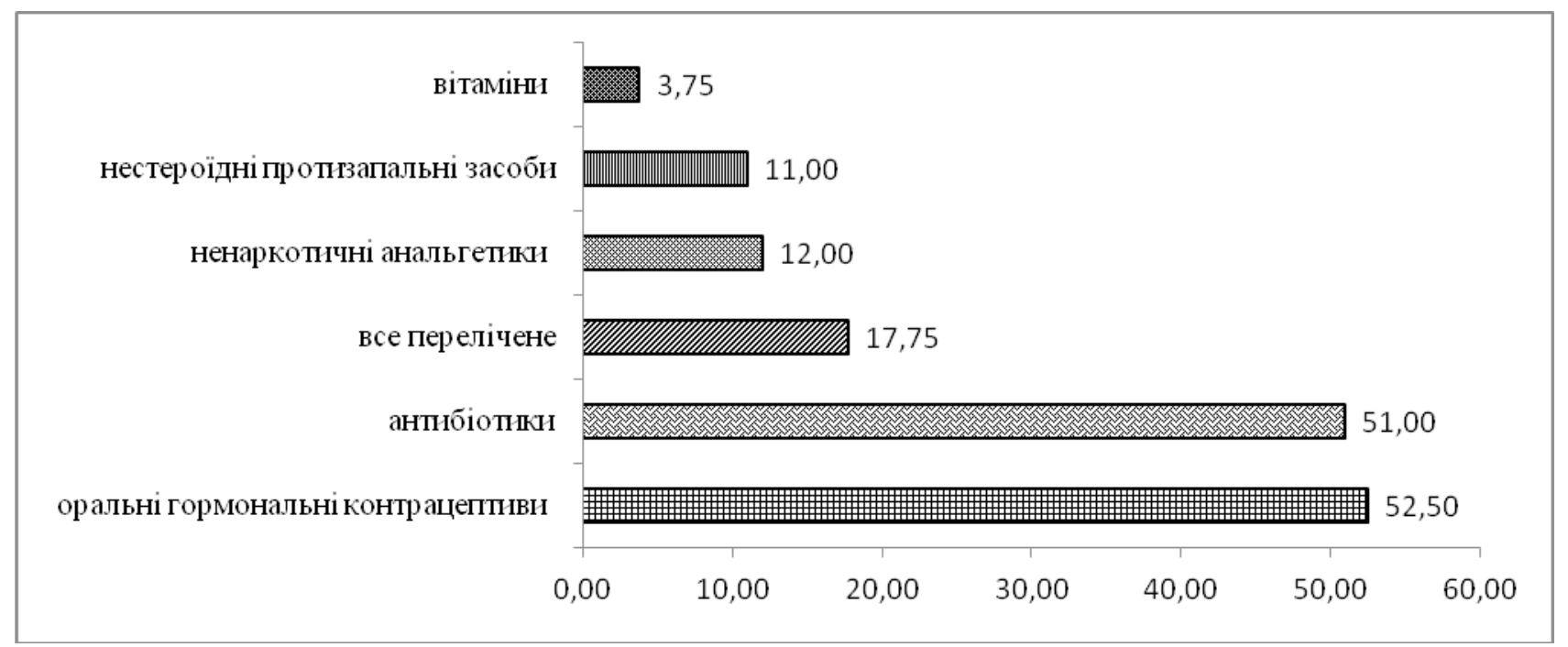

Рис. 3. Розподіл відповідей респондентів (випадки на 100 анкетованих) стосовно того, які ліки, на їхню думку, повинні відпускатися без рецепта.

Висновки. 1. Більшість анкетованих $(91,50 \pm 1,39) \%$ зазначила, що займались самолікуванням. За даними їх самооцінки, 3-поміж них у 64,5 \% не відбулося досягнення терапевтичного еоректу лікарського засобу; водночас ця частка може бути суттєво більшою у випадку залучення кваліфікованих медичних фрахівців до процесу оцінки результатів фрармакотерапії.

2. Підставами для придбання ліків при гострих захворюваннях найчастіше $€$ призначення лікаря та особистий досвід респондента. Інформації з інтернет-сайтів та реклами по радіо і телебаченню довіряє незначна частка анкетованих $(11,5 \pm 2,2) \%$.
3. Підставами для придбання ліків при хронічних захворюваннях аналогічно найчастіше $є$ призначення лікаря. Практично вдвічі меншу частку займає особистий досвід респондента. Водночас рекламі по радіо та телебаченню в питаннях лікування хронічних захворювань не довіряв жоден із опитаних.

4. Більшість респондентів $(64,00 \pm 2,40) \%$ визнала, що зазвичай приймають більше одного лікарського засобу одночасно. Вважають адекватною кількість ліків, призначених водночас до 5-ти лікарських засобів. Кожен 2-й анкетований називає поліпрагмазією (поліфармацією) одночасне приймання 6-х та більше ліків.

ISSN 2312-0967. Pharmaceutical review. 2018. № 3 
5. Перед прийманням ліків інструкцію до медичного застосування лікарського засобу вивчає більшість респондентів. Тоді як незначна частка респондентів $(4,00 \pm 0,98) \%$ не ознайомлюється 3 інструкцією ніколи. При цьому 1/3 анкетованих самовільно збільшувала дозу лікарського засобу. Кожен 2-й респондент визнав, що змінював призначені лікарем ліки на більш дешеві аналоги.
6. Кожен 2-й опитаний вважає, що за рецептом мають відпускатися оральні гормональні контрацептиви та антибіотики. Також кожен 2-й респондент при одному зверненні в аптеку витрачає суму від 100 до 300 грн.

7. Отримані результати, на нашу думку, повинні стати основою у комплексній моделі програми попередження негативних наслідків самолікування, особливо серед молоді.

\section{ОТНОШЕНИЕ К ПРОЦЕССУ САМОЛЕЧЕНИЯ СОИСКАТЕЛЕЙ ВЫСШЕГО МЕДИЦИНСКОГО ОБРАЗОВАНИЯ НА ДО- И ПОСЛЕДИПЛОМНОМ ЭТАПЕ (СОГЛАСНО РЕЗУЛЬТАТАМ СОЦИОЛОГИЧЕСКОГО ИССЛЕДОВАНИЯ)}

\section{Н. И. Заремба, А. Б. Зименковский}

Львовский национальный медицинский университет имени Данила Галицкого natalyazaremba@gmail.com

Цель работы. Предупреждение негативных последствий самолечения на основе его изучения и анализа поведения по этому вопросу соискателей высшего медицинского образования и курсантов-медиков.

Материалы и методы. Исследование проводилось по результатам социологического опроса 400 (p<0,05) соискателей образования на до- и последипломном этапе во Львовском национальном медицинском университете имени Даниила Галицкого. Полученный путем анкетирования первичный научный материал был проанализирован с использованием статистического и структурно-логического методов с учетом принципов системности. При статистическом анализе полученных данных был проведен расчет относительных величин и их погрешностей. Использованы методы: системного анализа, статистический, социологический, сравнения.

Результаты и обсуждение. По результатам социологического исследования установлено, что подавляющее большинство соискателей высшего медицинского образования на до- и последипломном этапе самостоятельно назначали лечение. Основаниями для приобретения лекарств при острых и хронических заболеваниях чаще всего являлось назначение врача и личный опыт опрошенных. Треть анкетируемых самовольно увеличивали дозу лекарств. Каждый 2-й респондент признался, что заменял назначенные врачом лекарственные средства на более дешевые аналоги. Каждый 2-й опрошенный считает, что по рецепту имеют отпускаться оральные гормональные контрацептивы и антибиотики.

Выводы. Полученные и проанализированные результаты выполненного социологического исследования свидетельствуют, что подавляющее большинство анкетируемых $(91,50 \pm 1,39)$ \% подтвердили, что занимались самолечением. По данным их самооценки, среди них в 64,5 \% не произошло достижения терапевтического эфрфекта лекарств. Большинство респондентов $(64,00 \pm 2,40) \%$ признали, что обычно принимают более одного лекарственного средства одновременно. Перед приемом лекарств инструкцию к медицинскому применению лекарственного средства изучает большинство респондентов. Полученные результаты, по нашему мнению, должны стать основой в комплексной модели программы предупреждения негативных последствий самолечения, особенно среди молодежи.

Ключевые слова: социологическое исследование; самолечение; соискатели высшего медицинского образования на до- и последипломном этапе; лекарственные средства; полипрагмазия.

\section{ATTITUDE TO THE PROCESS OF SELF-MEDICATION OF APPLICANTS OF HIGHER MEDICAL EDUCATION AT PRE- AND POSTGRADUATE STAGE (ACCORDING TO RESULTS OF THE SOCIOLOGICAL SURVEY)}

\section{N. I. Zaremba, A. B. Zimenkovsky}

Danylo Halytsky Lviv National Medical University

natalyazaremba@gmail.com

The aim of the work. Preventing the negative consequences of self-treatment on the basis of its study and analysis of behavior in this regard by the applicants of higher medical education and cadets-medics.

ISSN 2312-0967. Фармацевтичний часопис. 2018. № 3 
Materials and Methods. The research was conducted according to the results of a sociological survey of 400 ( $p<0.05$ ) applicants of education at the pre- and postgraduate stage at the Danylo Halytsky Lviv National Medical University. The primary scientific material obtained through questionnaires was analyzed using statistical, methodological and logical methods taking into account the principles of systemacity. In the statistical analysis of the obtained data, the calculation of relative variables and their errors was made. The following methods were used: system analysis, statistical, sociological, comparison.

Results and Discussion. According to the results of a sociological survey, it was found that the vast majority of applicants of higher medical education at the pre- and postgraduate stage independently prescribed treatment to themselves. The reasons to buy medicines due to acute and chronic diseases were often the prescription of a doctor and the personal experience of the interviewees. A third of those questioned arbitrarily increased the dose of the drugs. Every 2nd respondent admitted that he replaced the prescribed medicines for cheaper analogues. Every 2nd respondent believed that the oral hormonal contraceptives and antibiotics should be sold without the prescription.

Conclusions. The results of the conducted sociological research, which were obtained and analyzed, confirmed that the vast majority of questionnaires $(91.50 \pm 1.39 \%)$ stated that they treated themselves. According to their self-assessment, $64.5 \%$ of them did not achieve the therapeutic effect of medicines. Most respondents $(64.00 \pm 2.40 \%)$ acknowledged that they usually took more than 1 drug at a time. The most respondents read the instruction for the medical use of the medicines before taking the drug. In our opinion, the obtained results should become the basis for a comprehensive model of the program of prevention of negative consequences of self-medication, especially among young people.

Key words: sociological survey; self-medication; applicants of higher medical education at the pre- and postgraduate stage; medicines; polypragmasia.

\section{Список літератури}

1. Кубзина Е. Р. Самолечение - вред или польза? / Е. Р. Кубзина // Bulletin of Medical Internet Conferences. 2014. - № 4. - С. 860.

2. Андреева И. В. Распространенность самолечения в мире / И. В. Андреева // Вісник орармакології та фрармації. - 2010. - № 3. - С. 14-24.

3. Безрецептурный отпуск и самолечение / Л. Б. Оконенко, Г. А. Антропова, Е. С. Егорова, Г. Г. Брыжахин // Вестник РУДН. Серия Медицина. - 2009. - № 4. - С. 42-46.

4. Андреева И. В. Самолечение - terra incognita лекарственной терапии / И.В.Андреева // Клиническая фрармакология и терапия. - 2007. - № 16. - С. 90-96.

5. Роль провізора в успішній реалізації концепції

\section{References}

1. Kubzina ER. [Self-medication is harm or benefit?] Bulletin of Medical Internet Conferences 2014;4: 860. Russian. 2. Andreyeva I. [Prevalence of self-medication in the world]. Visnyk farmakolohii ta farmatsii 2010;3:14-24. Russian.

3. Okonenko LB, Antropova GA, Egorova ES, Bryzhakhin GG. [Sale without a prescription and self-medication]. Vestnik RUDN. Seriya Meditsina 2009;4:42-46. Russian.

4. Andreyeva IV. [Self-medication - terra incognita of drug therapy]. Clinical Pharmacology and Therapy 2007;16: 9096. Russian.

5. Masheiko AM, Podpletnia OA, Zaiarskyi MI. [The role of the pharmacist in the successful implementation of the відповідального самолікування / А. М. Машейко, О. А. Подплетня, М.І. Заярський[таін.]// Фармацевтичний журнал. - 2011. - № 3. - С. 27-33.

6. Самолікування - плюси та мінуси. Режим доступу: http:// ronmb.org.ua/articles/samolikuvannya-plyusi-ta-minusi.html.

7. Зупанец И. А. Фармацевтическая опека на страже ответственного самолечения: путь от острых дискуссий к взаимопониманию / И. А. Зупанець // Therapia (Український медичний вісник). - 2012. - № 2. - С. 4-8. 8. Подплетня О. А. Результати впровадження концепції відповідального самолікування у Дніпропетровську / О. А. Подоплетня // Одеський медичний журнал. - 2011. - № 5. - С. 27-30.

concept of responsible self-medication]. Farmatsevtychnyi zhurnal 2011;3: 27-33. Ukrainian.

6. [Self-medication - the pros and cons]. Available from: http://ronmb.org.ua/articles/samolikuvannya-plyusi-ta-minusi.html. Ukrainian.

7. Zupanets IA. [Pharmacy guardianship of responsible self-medication: A way from acute discussions to mutual understanding]. Therapia (Ukrainskyi medychnyi visnyk). 2012;2: 4-8. Russian.

8. Podpletnya OA. [Results of implementation of the concept of responsible self-medication in Dnipropetrovsk]. Odeskyi medychnyi zhurnal 2011;5:27-30. Ukrainian. 